\title{
ON THE LIABILITY OF TRAVEL AGENTS: CONSTRUCTION, IMPLIED TERMS AND VICARIOUS PERFORMANCE
}

\author{
Andrew Phang*
}

\section{INTRODUCTION AND FACTS}

It has never been controverted that a party can, save in exceptional circumstances, delegate performance of the contract to another. ' It is, however, equally well-established that that party will be liable for any breach of contract that occurs as a result. ${ }^{2}$ In Wong Mee Wan v. Kwan Kim Travel Ltd., ${ }^{3}$ a Privy Council decision on appeal from the Court of Appeal of Hong Kong, the Board examined the boundaries of such liability in a context of great practicality; first, because the situation was a common one concerning the liability of a travel agent and, secondly, because of the pragmatic lessons that result from the decision in the case itself. The use of the device of the implied term by the Board will be explored briefly.

The facts could not be more straightforward. The plaintiff was in fact, the

- Associate Professor, Faculty of Law, National University of Singapore. I would like to express my deepest appreciation to my wife, Dr.Phang Sock Yong, Senior Lecturer, Department of Economics and Statistics, National University of Singapore, for her very helpful comments and suggestions. All errors, however, remain mine alone.

${ }^{1}$ See Chitty on Contracts, Vol.1 (27th.ed., Sweet \& Maxwell, 1994) at para.19-046 at 987. See also Davies v. Collins [1945] 1 All E.R. 247. Cf. Investors in Industry Commercial Products Ltd. v. South Bedfordshire District Council [1986] 1 All E.R. 787 at 807-808.

On the other hand, the strict primary liability of a carrier to exercise due diligence under the Hague Rules as embodied in the leading decision of the House of Lords in Riverstone Meat Co. Pty. Ltd. v. Lancashire Shipping Co. Ltd. [1961] A.C. 807 may, it is suggested, be explained by the unique statutory regime concerned, as well as the established interpretation thereof.

${ }^{2}$ Chitty on Contracts, ibid at para.19-046 at 987.

${ }^{3}$ [1996] 1 W.L.R. 38. 


\section{THE DENNING LAW JOURNAL}

mother and administratrix of her deceased daughter, who had been killed as a result of negligence on the part of the employee of the third defendant, who provided a speedboat service across a lake in the People's Republic of China (P.R.C.). A collision on the lake had resulted in two deaths by drowning, one of which involved the plaintiff's daughter. The first defendant, a travel agent with a registered office in Hong Kong, had contracted with the plaintiff's daughter for a group package tour in the P.R.C., whilst the second defendant, a travel agency based in the P.R.C. itself, was apparently responsible for the actual conduct of the tour. ${ }^{4}$ The plaintiff brought actions against all three defendants for breach of contract and negligence. She succeeded at first instance against all of them, and only the first defendant appealed to the Court of Appeal, which allowed its appeal. ${ }^{5}$ The Board, however, reversed this decision, allowing the plaintiff's appeal. In summary, it held that the first defendant had undertaken to supply the services and that, in the circumstances of the case, there was an implied term that those services would be carried out with reasonable skill and care. On the facts, such reasonable skill and care was lacking; in the words of the Board:

"The trip across the lake was clearly not carried out with reasonable skill and care in that no steps were taken to see that the driver of the speedboat [who was an employee of the third defendants] was of reasonable competence and experience and the first defendant is liable for such breach of contract as found by the trial judge. ${ }^{.6}$

\section{THE CENTRALITY OF CONSTRUCTION}

The main issue in the case was this: did the first defendant merely promise to "arrange" for the tour, thus taking no responsibility for any default by those who actually provided the services ${ }^{7}$ or did it go further, undertaking to provide for the services, notwithstanding the fact that some of the services would be carried out by others (here, by the second and third defendants who were located in the

${ }^{4}$ Although there was a tour leader employed by the first defendants, it is not unsurprising that the actual tour guide was employed by the second defendants.

${ }^{5}$ See [1994] 1 H.K.C. 308

${ }^{6}$ Supra.n.3 at 46 (emphasis added).

' Or, as the Board put it, "at most a liability to take reasonable care in the selection of those who provided the services" - ibid. 


\section{ON THE LIABILITY OF TRAVEL AGENTS}

actual country of the tour itself). As has been seen, the court decided in favour of the latter. What is involved here is, of course, no specific doctrine as such, but, rather, the much broader concept of construction of the terms of the contract itself, presumably arrived at on an objective basis. ${ }^{8}$ In point of fact, however, the possibility (at least) for uncertainty is potentially great, and the line between a promise merely to "arrange" as opposed to a promise to undertake wholly may often be a fine one, not least because the objective of objectivity is not, it is suggested, wholly attainable in practice as such, given the myriad permutations of factual circumstances. ${ }^{9}$ The net result is a reasonable disagreement based on differences in perception and interpretation of the same contractual terms and their general factual matrix. In the instant case, for example, Penlington J.A. (in the Hong Kong Court of Appeal) was of the view that "[i[t would .....impose an intolerable burden if the firm which put the tour package together was to be held liable for the negligence of a transport operator in another country on the basis of a breach of a non-delegable primary contractual duty." ${ }^{10}$ Lord Slynn of Hadley, who delivered the judgment of the Board, however, took a different view, stating that even if the deceased had realized that parts of the tour would be actually conducted by others (here, the second and third defendants), "[t]hat does not, however, conclude the question." 11

This is a double-edged argument, since it could be argued, with equal persuasion, it is submitted, that the fact that the first defendant was based in Hong Kong gave rise to the inference that it was merely arranging the tour, since, in the nature of things and, arguably, practice, the actual conduct of the tour is undertaken by other tour agencies based in the country of the tour itself (as was, in fact, the case here); any participation by an actual employee was

${ }^{8}$ Supra.n.3 at 42. See also Craven et al v. Strand Holidays (Canada) Ltd.et al (1982) 40 O.R.(2d.) 186 (which was in fact cited in the instant case) and Davies v.Collins supra.n. 1 at 250 per Lord Greene M.R.

${ }^{9}$ Though $c f$. the emphasis by certain writers on the concept of construction in the context of common mistake: see e.g. Slade, "The Myth of Mistake in the English Law of Contract" (1954) 70 L.Q.R. 385; Atiyah, "Couturier v. Hastie and the Sale of Non-Existent Goods" (1957) 73 L.Q.R. 340; Atiyah \& Bennion, "Mistake in the Construction of Contracts" (1961) 24 M.L.R. 421; and Atiyah, "Judicial Techniques and the English Law of Contract" (1968) 2 Ottawa.L.Rev. 337 (reprinted as Essay 9 in Atiyah, Essays on Contract (Clarendon, 1986).

${ }^{10}$ Supra.n.5 at 316.

${ }^{11}$ Supra.n.3 at 45. 


\section{THE DENNING LAW JOURNAL}

likely to be minimal (again, as was the situation in the present case). ${ }^{12}$ However, Lord Slynn then proceeded to draw the distinction between "arranging" and "undertaking" mentioned above, deciding (as has been seen) that the latter had been intended on the terms of the contract itself. Further, whilst acknowledging the point from hardship, the learned judge was of the view that the first defendant in the present case could have protected itself by insurance cover or by the inclusion of an exception clause in the contract. ${ }^{13}$

It is, however, respectfully submitted that a close examination of the contractual terms as set out in the first defendant's brochure reveals that they are ambiguous at best; they constitute, in essence, the itinerary. ${ }^{14}$ It is true that the Board did refer to the heading of the brochure which read thus: "Kwan Kin Travel Tours [i.e. the first defendant] everything more comprehensively and thoughtfully worked out;" it was of the opinion that this heading gave "some indication that it is the first defendant who has undertaken the task of supplying the package tours." ${ }^{15}$ However, this is hardly conclusive; nor, with respect, is the Board's reference to the use of the word "we" in the itinerary persuasive since, contrary to the Board's interpretation, it could indeed be argued that the word was intended in a colloquial and conversational sense reminiscent of the many travel itineraries in the region with which the present writer is familiar. ${ }^{16}$ The Board also referred to other particulars in the itinerary which, in its view, did not indicate a relinquishment of responsibility on the part of the first defendant, including the right of the same to change the means of transport. Even this last mentioned point does not, it is suggested, necessarily entail the full assumption

${ }^{12}$ The tour group in the present case was accompanied by a tour leader employed by the first defendant, but, to all intents and purposes, she performed merely liaison duties, the actual conduct of the tour being arranged (at the material time) by a tour guide employed by the second defendants who were, of course, based in the P.R.C. itself. See also supra.n.4.

13 The reference was to an "exemption clause"; this, however, suggests an attempt to obtain total exemption from liability, whereas the term "exception clause" would include attempts to limit liability as well. Cf. Davies v. Collins supra.n.1 at 250-251 per Lord Greene M.R. on the role of exception clauses as an operative factor - as indicating a tendency against sub-contracting and consequent personal undertaking, since the ambit of loss to the consumer would otherwise be unduly extended notwithstanding the limitation of the supplier's liability.

${ }^{14}$ See supra.n. 3 at 45 .

${ }^{15}$ Ibid. at 46.

${ }^{16} \mathrm{Ibid}$ 


\section{ON THE LIABILITY OF TRAVEL AGENTS}

of responsibility the Board attributed to the first defendant. The Board, further, pointed to the fact that if no legal remedy was forthcoming against the package tour operator (here, the first defendant), the plaintiff would have had to have pursued her claim in a foreign jurisdiction (here, the P.R.C.), together with all the difficulties such a course of action entailed. ${ }^{17}$

Finally, it referred to regulation 15 of the U.K. Package Travel, Package Holidays and Package Tours Regulations $1992{ }^{18}$ by analogy, which regulation states, inter alia, that the organiser of a package tour "is liable to the consumer for the proper performance of the obligations under the contract, irrespective of whether such obligations are to be performed by that other party or by other suppliers of services but this shall not affect any remedy or right of action which that other party may have against those other suppliers of services." ${ }^{19}$ However, this only raises the issue as to whether or not something along these lines ought to be instituted (in this case in Hong Kong).

Can it not be argued, then, that travel agencies as well as others in a similar position can simply avoid liability by clearly specifying that it is merely "arranging" for tours as opposed to undertaking responsibility and liability under contract? If so, the instant case comes as a poignant lesson for travel agencies that will not have to be experienced again in the future. The solution is not so clear-cut; the travel agency concerned would still be liable if it were personally negligent (in this instance, in the process of selection). ${ }^{20}$ It could, of course, attempt to escape or limit liability by way of an exception clause, but such a clause would then be subject to both common law and (where applicable) statutory rules. Indeed, in the instant case itself, the Board suggested the possibility of expressly including such a clause. However, it should be noted that any exception clause in the present context would have been subject to both the

\section{deliberations.}

${ }^{17}$ Quaere whether this was an important (at least subconscious) factor in the Board's

${ }^{18}$ S.I.1992/3288.

${ }^{19}$ Regn. 15(1)(emphasis added). Cf. Regn.15(2), the primary part of which was stated by the Board as follows: "[T] he other party to the contract is liable to the consumer for any damage caused to him by the failure to perform the contract or improper performance of the contract...", there follow exceptional circumstances that are both reasonable and self-explanatory in nature.

${ }^{20}$ See Clerk \& Lindsell on Torts (17th.ed., Sweet \& Maxwell, 1995) at para.5-46 at 193. See also Saper v. Hungate Builders Ltd. [1972] R. T.R. 360. 


\section{THE DENNING LAW JOURNAL}

common law as well as the Control of Exemption Clauses Ordinance, ${ }^{21}$ which is modelled almost entirely on the U.K. Unfair Contract Terms Act 1977. ${ }^{22}$ Anyone even remotely familiar with the law relating to exception clauses will immediately realize that an exception clause may not easily pass muster, particularly (as in the present case) where there may be an inordinate difference in bargaining power, a factor, incidentally, that plays a significant role in the application of the test of reasonableness under the Act. Indeed, the test of reasonableness is itself a veritable minefield for a party seeking to take advantage of an exception clause, if nothing else, because of the high degree of uncertainty surrounding the application of the test itself. ${ }^{23}$

The net result appears to be that defendants such as the one here are in a Calch 22 situation, insofar as the aim is to avoid liability altogether. On a policy level, this may not be undesirable, since consumers are almost always likely to be in a position of relative weakness. However, as Penlington J.A. pertinently pointed out at the Court of Appeal stage, it is also unsatisfactory to impose a burden on a travel agent who is not only physically providing the services in question, but who is unable to supervise physically such provision. ${ }^{24}$ There is not, not unexpectedly, any clear answer either way. It is suggested, however, that the balance points in favour of the result arrived at in the instant case, but subject to the reservations expressed below with regard to the ultimate effect of such insurance coverage vis-a-vis the consumer. As the Board mentioned, parties in the position of the first defendant could arrange for the requisite insurance coverage, which could then be factored into the price charged for the tour concerned. Such an increase in prices need not necessarily disadvantage travel agencies if such a practice is in fact adopted industry-wide, particularly in light of the present decision. Would there be an incentive for travel agents to seek out

${ }^{21}$ No.59 of 1989; now Cap.71, Laws of Hong Kong; noted in Aitken, (1990) 20 H.K.L.J. 381.

${ }^{22}$ Cap.50. One notable difference is the power given in s.6 of the Hong Kong Ordinance to amend Schedules 1 and 2 of the same Ordinance by resolution.

${ }^{23}$ See generally, Adams \& Brownsword, "The Unfair Contract Terms Act: A Decade of Discretion" (1988) 104 L.Q.R. 94.

${ }^{24}$ There was no evidence (from the report at least) that the tour leader employed by the first defendant was intended to supply anything more than a basis liaison function: see also supra.n. 4 and n. 12 . 


\section{ON THE LIABILITY OF TRAVEL AGENTS}

insurance coverage? ${ }^{25}$ It is suggested that there would be in light of the present decision. It is, however, further suggested that insurance cover might not be, in the final analysis, in the consumer's favour because the security of insurance coverage would not encourage travel agents to attempt their level best to source out other travel agents in the country of performance with the best credentials, and not, as is conceivably the case, merely the ones with the cheapest rates. There would, in other words, be no incentive towards the taking of more care rather than less - the so-called "moral hazard" problem.

It is true, of course, that the consumer is theoretically better off insofar as his or her remedy is concerned, but one might well argue that the old adage that prevention is better than cure should be of the first importance, lest the horse be put before the cart. However, as one writer pertinently observes, this is not so easy to effect in practice. ${ }^{26}$ One possibility is for the requisite adjustment of the insurance premium in order to avoid covering the entire possible liability, although it will, in the nature of things, be extremely difficult for the insurer to gauge the possible extent of liability for each tour package. ${ }^{27}$ Another possibility is that the consumer purchases travel insurance, but the question then arises as to why the onus should be placed on him or her. The possible counter-argument, however, is that costs are likely to rise in any event if the travel agent obtains insurance coverage, since as already mentioned, this additional cost will be factored into the price charged to the consumer - although this latter approach may, given the inevitable rise in costs, be psychologically preferable insofar as the consumer's perception and satisfaction are concerned.

Would one further approach be for travel agents in the position of the first defendant to obtain indemnities from travel agents and sub-contractors in the country of performance? It is suggested that this would neither take care of the increase in prices for the consumer, nor encourage the parties concerned to take more care - problems already canvassed in the preceding paragraphs. The former

${ }^{25}$ Cf. Regn. 19 of the U.K. Package Travel, Package Holidays and Package Tours Regulations 1992 supra.n. 18, para. 1 of which reads "[T] he other party to the contract shall have insurance under one or more appropriate policies with an insurer authorised in respect of such business in a Member State under which the insurer agrees to indemnify consumers, who shall be insured persons under the policy, against the loss of money paid over by them under or in contemplation of contracts for packages in the event of the insolvency of the contractor."

${ }^{26}$ See Polinsky, An Introduction to Law and Economics (2nd.ed., Little, Brown and Company, 1989) at 56-57.

${ }^{27}$ Though $c f$. the tour operator itself: see Wilson v. Best Travel Ltd. [1993] 1 All E.R. 353. 


\section{THE DENNING LAW JOURNAL}

is not likely to take more care because it has the benefit of an indemnity upon which to fall back. The latter is likely to take out insurance and, if so, this is hardly likely to encourage the taking of more care unless the insurance premium is adjusted, and this, as has been seen, is extremely difficult for the insurer to effect. ${ }^{28}$ Also, the resulting increased costs will also be passed on to the consumer; indeed, even if no insurance is taken out, the latter will, a fortiori, levy higher charges vis-a-vis the former which would, of course, be passed on, in turn, to the consumer.

In addition, the Board also referred to the inclusion of an exception clause. As was also seen however, this approach is not clearly to the advantage of the travel agency concerned, since the clause would be necessarily subject to scrutiny by the courts along common law as well as statutory lines. It is suggested, however, that this is the lesser of two evils, for in a scenario such as occurred in the present case, the defendant would be in an even more intractable position. For all the lack of certainty, the defendant might still be able to escape liability should the exception clause pass muster, and, in any event, would have already covered its losses via insurance, as just discussed above. ${ }^{29}$

\section{IMPLYING TERMS}

Whilst the Board held that the first defendant had undertaken to supply the requisite services, it had to determine the scope of that duty. As has been seen, it was of the view that a term would be implied to the effect that the services would be carried out with reasonable skill and care, and that such skill and care had not been exercised in the circumstances of the case. Such a term was, presumably, implied "in fact" under the strict test of necessity. ${ }^{30}$ Given, however, the various possible interpretations canvassed above, it is suggested that the successful implication in the present case was not as clear an inference as the Board would want believed. It is suggested that it might have been preferable for

\footnotetext{
${ }^{28}$ See ibid. \& text.

${ }^{29}$ Cf. Wilson v. Best Travel Ltd. supra.n. 27.

${ }^{30}$ As to which, see the oft-cited cases of The Moorcock (1889) 14 P.D. 64 and Shirlaw
} v. Southern Foundries (1926) Ltd. [1939] 2 K.B. 206 affd. [1940] A.C. 701. See also, supra.n.3 especially at 4 .

It is true that the language of the Board may suggest a broader term implied "in law", but the earlier part of the judgment (where the general principle to be applied is mentioned) suggests otherwise: see generally supra. $n .3$ at $44 \& 47$. 


\section{ON THE LIABILITY OF TRAVEL AGENTS}

the Board to have implied a term "in law" instead. ${ }^{31}$ The potential problem, of course, is that in all future cases, a term would be, at least potentially, implied in contracts in this category. It is, however, suggested that this would pose no real obstacle in principle, if the distinction between merely "arranging" and "wholly undertaking" were accepted in the first instance. Somewhat ironically perhaps, the Board did canvass the broad problem as to whether or not such an implication would impose an "intolerable burden" on the first defendant, an approach that is actually more consistent with the implications of terms "in law." ${ }^{32}$ It could, of course, be argued that this point is inconclusive insofar as the courts have to consider broad considerations of reasonableness even with respect to terms implied "in fact," although reasonableness is necessary but not sufficient in and of itself for the successful implication of a term under this particular category.

\section{CONCLUSION}

The present decision is, it is suggested, of critical importance to travel agents, as future strategies are mapped out to deal with possible liability. As has been seen, however, the suggestions proffered by the Board, presumably to restore a balance to the overall situation, are not without problems, and which are therefore necessarily present even where industry practice might already incorporate them. The overall impact of insurance or indemnities is not as clear as it is assumed to be, and the inclusion of exception clauses by the travel agent is at best uncertain, and very much dependent on the ultimate interpretation of the court in the case itself.

${ }^{31}$ Notwithstanding possible misgivings about the entire category itself: see Phang, "Implied Terms in English Law - Some Recent Developments" [1993] J.B.L. 242.

${ }^{32}$ See supra.n.3 at 47 . See also supra.n. 10. 